\title{
Steady Augmentation of Anti-Osteoarthritic Actions of Rapamycin by Liposome-Encapsulation in Collaboration with Low-Intensity Pulsed Ultrasound [Corrigendum]
}

Chen CH, Kuo SM, Tien YC, Shen PC, Kuo YW, Huang HH. Int J Nanomedicine. 2020;15:3771-3790.

The authors have advised due to an error at the time of figure assembly, Figure 2B on page 3778 is incorrect. The correct Figure 2 is shown below.
The authors apologize for this error and advise it does not affect the results of the paper. 

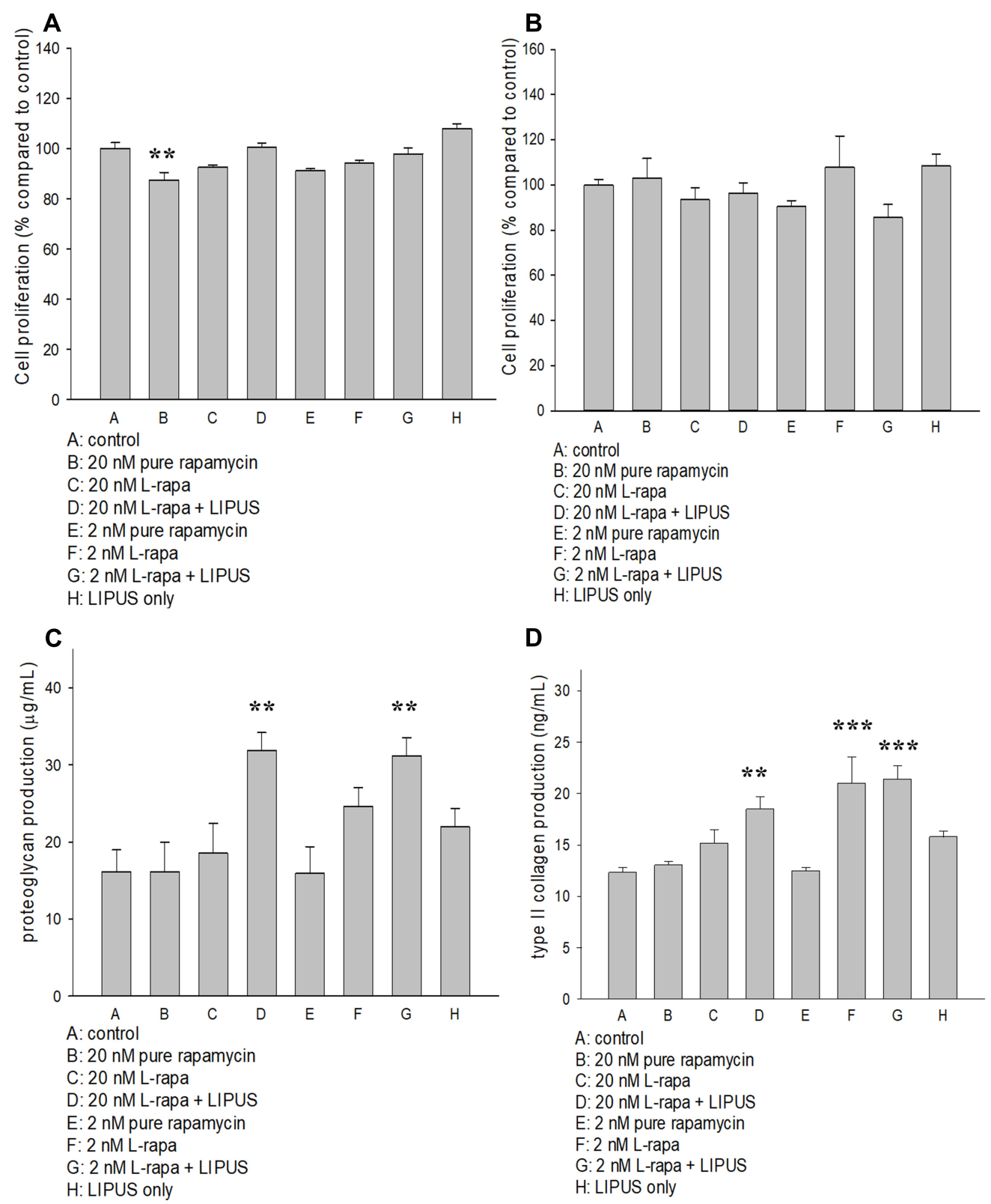

D

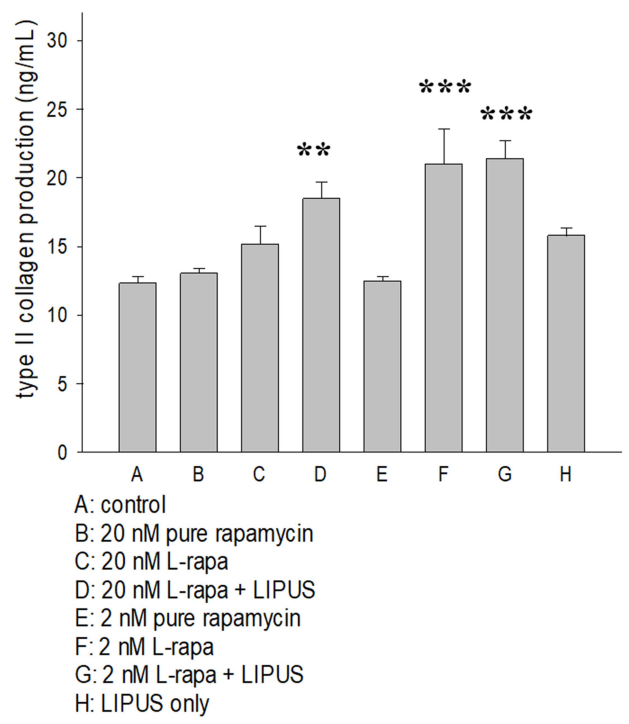

Figure 2 (A) Pure rapamycin at $20 \mathrm{nM}$ decreased human normal chondrocyte proliferation by about 15\% while (B) pure rapamycin and L-rapa with or without LIPUS did not cause significant effects on HOAC proliferation. (C) L-rapa at $20 \mathrm{nM}$ and $2 \mathrm{nM}$ in collaboration with LIPUS approximately doubled proteoglycan production in human normal chondrocytes cultured in alginate beads. (D) L-rapa at $2 \mathrm{nM}$ alone and in combination with LIPUS increased type II collagen production by around I.7-folds in human normal chondrocytes cultured in alginate beads (PG: proteoglycan; **P<0.01; ***P<0.00I; by one-way ANOVA, $N=5$ ).

\section{Publish your work in this journal}

The International Journal of Nanomedicine is an international, peerreviewed journal focusing on the application of nanotechnology in diagnostics, therapeutics, and drug delivery systems throughout the biomedical field. This journal is indexed on PubMed Central, MedLine, CAS, SciSearch ${ }^{\mathbb{B}}$, Current Contents ${ }^{\mathbb{B}} /$ Clinical Medicine,
Journal Citation Reports/Science Edition, EMBase, Scopus and the Elsevier Bibliographic databases. The manuscript management system is completely online and includes a very quick and fair peer-review system, which is all easy to use. Visit http://www.dovepress.com/ testimonials.php to read real quotes from published authors. 